\title{
Evaluasi manajemen dan penanganan cedera muskuloskeletal di laboratorium klinik terapi fisik FIK UNY dengan model CIPP
}

\author{
Fendi Nugroho*, Wara Kushartanti, Guntur \\ Program Studi Ilmu Keolahragaan, Program Pascasarjana, Universitas Negeri Yogyakarta. \\ Jalan Colombo No. 1, Karangmalang, Yogyakarta 55281, Indonesia \\ * Coressponding Author. E-mail: fendinugrohofikuny@gmail.com
}

\begin{abstract}
Received: 14 August 2021; Accepted: September 13, 2021 Published: September 25, 2021
Abstrak: Penelitian ini bertujuan untuk mengungkapkan evaluasi manajemen dan penanganan cedera muskuloskeletal di Laboratorium Klinik Terapi Fisik Fakultas Ilmu Keolahragaan (FIK) Universitas Negeri Yogyakarta (UNY) dilihat dari (1) context, (2) input, (3) process, dan (4) product (CIPP). Penelitian ini menggunakan desain penelitian evaluatif dengan pendekatan diskriptif kualitatif dan kuantitatif. Subjek penelitian ini yaitu manajer, masseur, pasien Klinik Terapi Fisik Klinik Terapi Fisik FIK UNY. Pengumpulan data dilakukan dengan tiga metode, yaitu kuisioner, wawancara dan observasi. Analisis data dengan melakukan pereduksian data, penyajian data, pemberian kesimpulan. Hasil penelitian evaluasi manajemen di Laboratorium Klinik Terapi Fisik FIK UNY adalah sebagai berikut, (1) dalam hal context, keberadaan klinik telah sesuai dengan kebutuhan masyarakat dan bertujuan untuk memberikan pelayanan kepada masyarakat sebagai bentuk pengabdian lembaga kepada masyarakat. 2) Dalam hal input, manajemen dalam kategori sangat baik (51\%). 3) Dalam hal process, di Laboratorium Klinik Terapi Fisik FIK UNY memiliki program dalam kategori baik (64\%). 4) Dalam hal product, hasil layanan masuk dalam kategori sangat baik. Rekomendasi untuk pihak FIK UNY dan manajemen selaku pengelola adalah perlunya perbaikan pada tempat tunggu pasien yang diperluas dan sarana prasarana secara berkala dilakukan pengecekan.
\end{abstract}

Kata Kunci: evaluasi, manajemen, cedera, muskuloskeletal, model CIPP.

\section{Management evaluation and treatment of muskuloskeletal injury physical therapy clinic FIK UNY with CIPP model}

\begin{abstract}
The research was purposed 1) know the evaluation of management and treatment of musculoskeletal injury in Phisical Therapy Clinic FIK UNY seen from the context, 2) know the evaluation of management and treatment of musculoskeletal injury in Phisical Therapy Clinic FIK UNY seen from the input, 3) know the evaluation of management and treatment of musculoskeletal injury in Phisical Therapy Clinic FIK UNY seen from the process, 4) know the evaluation of management and treatment of musculoskeletal injury in Phisical Therapy Clinic FIK UNY seen from the product. This research using evaluative design with qualitative and quantitative descriptive approach. The subject of this research is manager patients of Physical Therapy Clinic FIK UNY, masseur patients of Physical Therapy Clinic FIK UNY, and patients of Physical Therapy Clinic FIK UNY. Data collection technique is done by three methods, namely questionnaire, interview and observation. Data analysis includes data reduction, data presentation, conclusion drawing. The results of the management evaluation of the Physical Therapy Clinic of FIK UNY are as follows, 1) In term of the context, the operation of Physical Theapy Clinic FIK UNY has been in accordance with the needs of the community and aims to provide services to the community as a form of community service, 2) In term of the input, the management of the input is in a very good category (51\%)., 3) The management of the process is in a good category (64\%). 4) The product management is in a very good. Recommendations for the FIK UNY and management as managers are the need for improvements to the expanded patient waiting area and periodic checks on infrastructure facilities.
\end{abstract}

Keywords: CIPP model, evaluation, management, muskuloskeletal, injury.

How to Cite: Nugroho, F., Kushartanti, W., \& Guntur, G. (2021). Evaluasi manajemen dan penanganan cedera muskuloskeletal di laboratorium klinik terapi fisik FIK UNY dengan model CIPP, 9(2), 268-278. doi: https://doi.org/10.21831/jk.v9i2.43139 
Jurnal Keolahragaan, 9 (2), 2021-269

Fendi Nugroho, Wara Kushartanti, Guntur

\section{PENDAHULUAN}

Negara Inggris pada tahun 2000 telah melakukan penelitian berupa survei tentang kontribusi Complementer Alternatife Medecine (CAM), dengan hasil penelitian menunjukan $90 \%$ orang memilih menggunakan dengan alasan biaya yang lebih murah dan efektif (Ernst, 2000). Diperkuat oleh hasil penelitian yang dilakukan oleh Barnes et al (2004) selama 12 bulan terakhir terdapat $62 \%$ orang dewasa menggunakan beberapa bentuk terapi $C A M$ dan terdapat 10 jenis terapi yang paling umum digunakan yaitu doa khusus untuk seseorang kesehatan sendiri $(43,0 \%)$, doa oleh orang lain untuk seseorang kesehatan sendiri $(24,4 \%)$, produk alami $(18,9 \%)$, latihan pernapasan $(11,6 \%)$, partisipasi dalam kelompok doa untuk kesehatan sendiri $(9,6 \%)$, meditasi $(7,6 \%)$, perawatan chiropractic $(7,5 \%)$, yoga $(5,1 \%)$, pijat $(5.0 \%)$, dan terapi pola makan $(3,5 \%)$. CAM paling sering digunakan untuk mengobati nyeri punggung atau masalah punggung, kepala atau pilek, sakit leher atau leher masalah, nyeri sendi atau kekakuan, dan kecemasan atau depresi.

Perkembangan bentuk terapi $C A M$ di Indonesia salah satunya yaitu bentuk terapi dnegan menggunakan pijat atau masase. Khusus di Daerah Istemewa Yogyakarta telah dikembangkan di Laboratorium Klinik Terapi Fisik Fakultas Ilmu Keolahragaan (FIK) Universitas Negeri Yogyakarta (UNY). Unit berfungsi sebagai tempat penelitian, tempat praktik lapangan dan tempat pelayanan jasa bagi masyarakat serta penerapan aplikasi langsung dari disiplin ilmu bidang keahlian terapi dan rehabilitasi prodi Ikor yang telah diberikan dalam proses perkuliahan. Keberadaan unit jasa pelayanan di FIK pada saat ini sudah sesuai dengan Tri Dharma Perguruan yang terdiri dari 3 (tiga) poin, yaitu 1) Pendidikan dan Pengajaran 2) Penelitian dan Pengembangan 3) Pengabdian kepada Masyarakat.

Pelayanan jasa masase ditawarkan dan yang menjadi sasaran adalah kepada masyarakat umum yang mengalami gangguan fungsi otot dan sendi dengan gejala ringan atau tingkat I (satu) serta juga bagi masyarakat yang mengalami kelelahan akibat aktivitas sehari-hari. Salah satu tolak ukur dari kemajuan dan kesuksesan dari Klinik Terapi Fisik FIK UNY tidak terlepas dari kepuasan yang dirasakan oleh konsumen terhadap manajemen, pelayanan dan jasa penanganan yang diterima, baik dilihat dari aspek biaya, waktu, sarana dan prasarana atau hasil akhir pulihnya pasien dari cedera dan kelelahan. Penerapan evaluasi yang dilakukan secara teratur dapat membantu pihak manajemen untuk mengetahui kondisi internal maupun eksternal dan data yang sudah ada dapat digunakan sebagai bahan evaluasi. Hasil penelitian Musanto (2004) sales experience memberikan kontribusi terbesar terhadap loyalitas pelanggan. Feedback dari konsumen diperlukan sebagai bentuk dari bagian evaluasi yang dapat bermnfaat untuk mengetahui tingkat kepuasan layanan yang diberikan.

Monitoring sistem manajemen dan pelaksanaan merupakan salah satu upaya untuk meningkatkan mutu kinerja dan pelayanan. Hasil penelitian Al-Khathami (2012) mengemukakan bahwa luaran dari penelitian evaluasi dapat berupa rekomendasi yang diberikan kepada pembuat kebijakan untuk diimplementasikan sehingga dapat meningkatkan program lebih efektif dan efisien.

Evaluasi kinerja dilakukan untuk mengetahui hasil pencapaian sasaran dan tujuan perusahaan dan karyawan. Perolehan data analisis ini sangat berguna untuk mengetahui adanya ketidak beresan yang terjadi dilingkup internal ataupun eksternal. Menurut Chyung (2015) evaluasi adalah salah satu langkah penting dalam proses peningkatan kinerja. Oleh karena itu suatu badan usaha yang bergerak pada bidang jasa perlu dievaluasi baik dari segi manajemen, pelayanan dan penanganan yang dilakukan.

Hasil kajian dari berbagai sumber dan pengamatan yang telah diungkapkan diatas maka peneliti ingin meneliti lebih dalam lagi tentang: "Evaluasi Manajemen dan Penanganan Cedera Muskuloskeletal dengan Model CIPP." Harapan peneliti dapat menggambarkan kondisi Klinik Terapi Fisik FIK UNY yang sudah berjalan dan dapat digunkan sebagai bahan acuan untuk mengambil kebijakan yang sudah ada. Penelitian ini bertujuan untuk mengevaluasi manajemen dan pelayanan penanganan cedera muskuloskeletal di Klinik Terapi Fisik FIK UNY dengan model CIPP.

Manfaat penelitian bagi Klinik Terapi Fisik FIK UNY dijadikan sebagai: 1) bahan kajian, informasi dan rekomendasi untuk manajemen penyelenggara, 2) menyelenggaraan dan melaksanakan implementasi kebijakan Fakultas dan Universitas dalam bidang pengabdian masyarakat. Bagi perkembangan Ilmu Keolahragaan sebagai: 1) Acuan study banding bahan kajian, informasi dan rekomendasi untuk prodi Ikor di setiap Perguruan Tinggi di Indonesia, 2) penghasil SDM ahli terapi fisik khususnya masseur dan masseus lulusan sarjana (strata 1) yang siap bekerja secara mandiri menyongsong era revolusi industri. Pendapat Mardapi (2012) evaluasi sebagai cara untuk 
Jurnal Keolahragaan, 9 (2), 2021-270

Fendi Nugroho, Wara Kushartanti, Guntur

meningkatkan kualitas pendidikan, selain itu menghasilkan informasi yang digunakan sebagai umpan balik dan pembenahan terhadap program pendidikan. Menurut Chairawati (2014) evaluasi suatu proses pengukuran, pengujian, dan hipotesis dalam mempertimbangkan nilai.

Sesuai dengan definisi evaluasi Kirana \& Ratnasari (2017) menyatakan tujuan evaluasi yaitu untuk evaluator melakukan evaluasi dengan memberikan penilaian tentang apapun yang dievaluasi baik manajemen, kerangka kerja, pengembangan program, pelaksanaan kinerja, pengukuran kinerja dan peningkatan kinerja. Evaluasi bermanfaat memberikan informasi tentang kinerja oleh pengambil keputusan untuk mempertimbangkan keberlangsungan program.

Prinsip evaluasi menurut Arifin (2009) yang harus diperhatikan antara lain: (1) berkelanjutan atau kontinuitas, dengan tujuan untuk mengetahui perkembangan sebuah evaluasi, (2) ekstensif pada suatu objek atau menyeluruh pada berbagai aspek, (3) adil dan obyektif yaitu harus didasarkan atas kenyataan data dan fakta yang sebenarnya, (4) kooperatif yaitu proses dalam kegiatan evaluasi perlu adanya kerjasama pihak-pihak yang terlibat, (5) praktis mengandung arti menyusun alat evaluasi yang dapat dan mudah digunakan untuk peneliti maupun orang lain. Diperkuat oleh pendapat Muryadi (2017) penilaian evaluasi program dilakukan sejak awal, mulai penyususnan rancangan, pelaksanaan dan hasil. Secara garis besar keberhasilan melakukan evaluasi dengan hasil yang dapat dipertanggungjawabkan dipegaruhi oleh pemilihan model evaluasi yang tepat sesuai dengan penetapan tujuan evaluasi.

Kelompok jenis dan model evaluasi menurut Stufflebeam \& Zhang (2017) model CIPP merupakan evaluasi yang sistematis dan berprinsip pada aspek konteks, input, proses, dan produk. Pertanyaan mendasar yang digunakan adalah: 1) perencana apa yang akan dilakukan? 2) kebutuhan apa yang diperlukan? 3) proses seperti apa yang sedang dilakukan? dan 4) bagaimanakah hasilnya?. Hasil penelitian Hakan \& Seval (2011) ada empat jenis item analisis faktor pada evaluasi model CIPP yang dilakukan pada kurikulum pendidikan dengan hasil instrument yang valid dan reliabel.

Hasil yang diuraikan diatas telah sependaat dengan kriteria Stufflebeam \& Zhang (2017) antara lain: 1) sebagai acuan atau petunjuk dan penunjang kegiatan yang telah dilaksanakan, 2) sebagai laporan catatatan, klasifikasi, resume, pengolahan dan penyajian data, serta catatan data keuangan organisasi, 3) untuk membantu mengetahui pelaksanaan organisasi yang berjalan secara efektif atau tidak, 4) untuk memahami fenomena oraganisasi yang terjadi, 5) digunakan sebagai penguat pengambilan keputusan, pelaksana organisasi, dan konsumen dan dijadikan panduan apakah program yang sudah berjalan dihentikan, diperbaiki atau dilanjutkan.

Hasil penelitian Hasan et al. (2015) mengemukakan bahwa model evaluasi CIPP sebagai panduan untuk merancang suatu program yang dapat diterapkan pada dunia pendidikan, manajemen, sebuah perusahaan dan institusi.

\section{METODE}

Penelitian ini menggunakan desain penelitian evaluatif dengan pendekatan diskriptif kualitatif dan kuantitatif (mix method) dengan rancangan The Convergent Parallel Design. Desain ini digunakan jika peneliti melakukan penelitian kuantitatif dan kualitatif secara bersamaan atau dalam fase yang bersamaan dalam suatu riset. Prioritas kedua metode sejajar atau equal dan kedua desan dijaga tetap independen baik dalam pengambilan data maupun analisis untuk kemudian baru dilakukan result mixes pada interpretasi keseluruhan. Pemiihan metode evaluasi menggunakan model CIPP agar selaras dengan tujuan yang hendak dicapai dari penelitian ini. Penentuan model evaluasi tergantung dari tujuan dan sasaran dari sebuah penelitian (Muryadi, 2017). Prosedur evaluasi dalam penelitain ini diadopsi agar selaras dengan tujuan penelitian ini antara lain: 1) menyusun rencana, 2) melakukan validasi, 3) mengolah dan menganalisis, 4) memberikan interprestasi dan menarik kesimpulan.

Subjek penelitian ini meliputi komponen yang dapat memberikan sumber data dan informasi baik berupa dokumentasi, tulisan, cetak dan sumber daya manusia (SDM) seperti: pelopor, manajer, masseur terdahulu, masseur sekarang, petugas front office dan pasien di Klinik Terapi Fisik FIK UNY. Pengumpulan data dilakukan dengan empat metode, yaitu observasi, wawancara, analisa dokumen dan kuisioner. Penelitian ini menggunakan uji validitas instrumen yang ditentukan melalui uji validitas isi dan uji realibititas. Pengujian reliabilitas dengan cara menggunakan rumus Alpha Cronbach. Instrumen dalam penelitian ini menggunakan angket tertutup dan jawaban yang telah tersedia. 
Jurnal Keolahragaan, 9 (2), 2021-271

Fendi Nugroho, Wara Kushartanti, Guntur

Instrumen pada penelitian memegang peranan penting dalam menentukan kualitas data. Kisi-kisi di dalam penelitian ini antara lain lembar observasi, angket, panduan wawancara, dan panduan dokumen.Validasi isi butir soal di ajukan kepada 3 (tiga) ahli untuk dilakukan penilaian dan masukan dengan kompetensi yang berbeda antara lain: ahli manajemen, evaluasi dan masase terapi. Analisis data dalam penelitian ini menggunakan Model Alir dengan tahapan antara lain, 1) melakukan pereduksian data penelitian, 2) melakukan penyajian data penelitian, dan 3) melakukan penarikan kesimpulan, selanjutnya untuk melakukan uji kebenaran data silakukan triangulasi sumber dan triangulasi metode.

\section{HASIL DAN PEMBAHASAN}

\section{Hasil}

Penelitian ini dilakukan di Klinik Terapi Fisik FIK UNY yang berada di Jl. Colombo No. 1 Depok, Sleman, Yogyakarta. Tujuan penelitian ini adalah untuk mengevaluasi manajemen dan penanganan cedera muskuloskeletal. Data penelitian diperoleh dengan menggunakan beberapa metode pengumpulan data diantaranya menggunakan kuesioner, wawancara, lembar observasi, penelusuran dokumentasi. Kuisioner dalam penelitian ini berisi sejumlah pernyataan dan wawancara yang harus dijawab oleh subjek, isi mencakup fakta, data, pengetahuan, konsep, pendapat, persepsi. Lembar observasi difokuskan terhadap aspek context, input, procces dan product, sedangkan penelusuran dokumentasi dilakukan dengan mencari sumber dokumen cetak maupun dokumen foto. Pada penelitian ini dilakukan triangulasi data dari hasil wawancara, observasi dan dokumen. Responden wawancara yang digunakan sebagai penguat hasil penelitian yaitu digunakan untuk memperoleh data dari pimpinan, masseur, pasien, dan digunakan untuk memperoleh data mengenai pelaksanaan manajemen penanganan cedera muskuloskeletal Klinik Terapi Fisik FIK UNY. Hasil analisis data penelitian disajikan dalam bentuk deskripsi kuantitatif yang meliputi nilai rata-rata, standar deviasi, median dan modus. Diskripsi kualitatif disajikan dengan dibuat kategorisasi data dalam 4 (empat) kategori yaitu sangat baik, baik dan cukup serta kurang. Kategorisasi data dibuat berdasarkan dari hasil data nilai rata-rata dan standar deviasi, selanjutnya dilakukan analisis data pada masing-masing butir pertanyaan sehingga diperoleh nilai dari masing-masing komponen evaluasi.

Penyajian data dikuatkan dan dilengkapi dengan hasil wawancara, observasi dan dokumentasi pada tiap-tiap materi yang saling terkait. Penyajian data dilakukan berdasarkan metode evaluasi CIPP (Contecxt, Input, Procces, Product). Hasil analisis data penelitian ini adalah sebagai berikut:

\section{Aspek Context}

Evaluasi pada aspek context dilakukan untuk mengetahui apakah program yang telah berjalan telah sesuai dengan kebutuhan masyarakat serta sesuai dengan tujuan yang telah ditetapkan. Data evaluasi context didapatkan meliputi dari hasil wawancara yang dilakukan pada pelopor, terapis awal, terapis sekarang, manajer, front office dan pasien. Hasil wawancara dari berbagai narasumber yang menjadi pelopor berdirinya klinik terapi fisik menjelaskan bahwa tujuan awal pendirian adalah sebagai laboratorium yang menunjang proses pengajaran pada mahasiswa Ikora jurusan terapi, lebih dari itu dapat digunakan juga sebagai bentuk pengabdian kepada masyarakat yang membutuhkan penanganan cedera. Hasil wawancara dengan beberapa pasien yang diplih secara acak menyebutkan bahwa Klinik Terapi Fisik FIK UNY sangat dibutuhkan oleh masyarakat dan membantu masyarakat yang membutuhkan terapi yaitu yang mengalami masalah kesehatan terutama yang mengalami cedera akibat olahraga ataupun akibat aktivitas sehari-hari serta keberadaan memang benar-benar karena adanya kebutuhan dari masyarakat. Hasil wawancara dari front office, manajer, dan pasien menjelaskan hal senada bahwa alur pelayanan meliputi beberapa tahap yaitu pendaftaran pasien, penanganan pasien dan penyelesaian administrasi, dimana alur tersebut sesuai dengan standar operasional prosedur alut pelayanan yang sudah dibuat dan dilaksanakan.

\section{Aspek Input}

Evaluasi pada aspek input atau masukan mencakup alur pelayanan, sarana dan prasarana, SDM dari manajemen dan penanganan cedera muskuloskeletal Klinik Terapi Fisik FIK UNY. 
Jurnal Keolahragaan, 9 (2), 2021-272

Fendi Nugroho, Wara Kushartanti, Guntur

Hasil analisis data input diperoleh skor terendah adalah 20,00 dan skor tertinggi adalah 44,00. Hasil analisis statistik deskriptif diperoleh rerata $(\mathrm{M})=35,90 ;$ Median $(\mathrm{Me})=37,00 ;$ Modus $(\mathrm{Mo})=$ 31,00 dan Simpangan Baku (SB) $=4,87$.

Kategorisasi data penelitian didasarkan pada nilai mean dan standar deviasi ideal atau teoritik. Aspek input terdiri dari 11 item. Nilai skor minimal skala input adalah sebesar 11 (1x11), skor maksimal sebesar 44 (4x11), sehingga diperoleh rentang skor sebesar 33 (44 - 33). Hasil perhitungan standar deviasi (SD) pada data yang terdistribusi normal memiliki 6 satuan standar, maka nilai SD sebesar 5,50 diperoleh dari (33:6), dan nilai mean teoritis sebesar 27,50 (11+33/2). Kategorisasi untuk aspek input disajikan pada tabel 1 berikut:

Tabel 1. Kategorisasi Data Input

\begin{tabular}{llll}
\hline Interval Skor & & $(\%)$ & Kategori \\
\hline$x \geq 35,75$ & 51 & 51,0 & Sangat baik \\
$27,50 \leq$ s.d $<35,75$ & 45 & 45,0 & Baik \\
$19,25 \leq$ s.d $<27,50$ & 4 & 4,0 & Cukup \\
$x<19,25$ & 0 & 0,0 & Kurang \\
Total & 100 & 100,0 & \\
\hline
\end{tabular}

Berdasarkan tabel di atas diketahui sebesar 51\% responden menyatakan aspek input dalam kategori sangat baik, sebesar $45 \%$ responden menyatakan aspek input dalam kategori baik. Responden yang menyatakan aspek input kategori cukup sebesar $4 \%$. Secara lebih jelas hasil kategorisasi data input dapat dilihat pada gambar diagram 1 berikut:

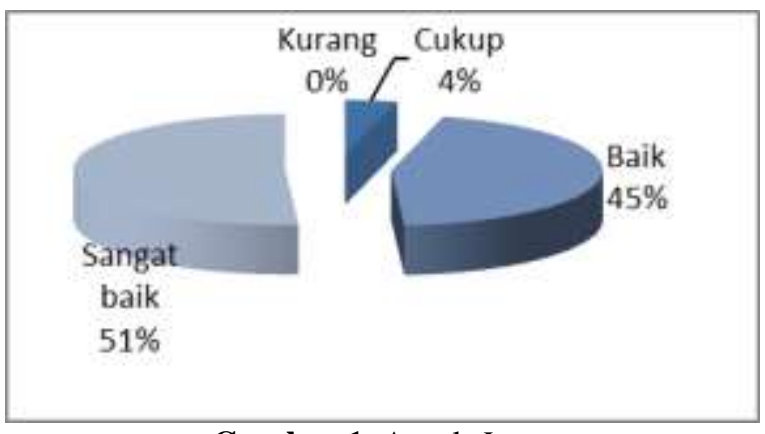

\section{Aspek Procces}

Gambar 1. Aspek Input

Evaluasi pada aspek program mencakup cara layanan, cara penanganan, sistem pelaporan dari manajemen dan penanganan cedera muskuloskeletal Klinik Terapi Fisik FIK UNY. Hasil analisis data program diperoleh skor terendah adalah 24,00 dan skor tertinggi adalah 48,00. Hasil analisis statistik deskriptif diperoleh rerata $(M)=40,75 ;$ Median $(\mathrm{Me})=41,00 ;$ Modus $(\mathrm{Mo})=37,00$ dan Simpangan Baku (SB) $=5,10$.

Kategorisasi data penelitian didasarkan pada nilai mean dan standar deviasi ideal atau teoritik. Aspek program terdiri dari 12 item. Nilai skor minimal skala program adalah sebesar 12 (1x12), skor maksimal sebesar 48 (4x12), sehingga diperoleh rentang skor sebesar $36(48-12)$. Perhitungan standar deviasi (SD) sebesar 6,00 diperoleh dari (36:6), dan nilai mean teoritis sebesar $30(48+12 / 2)$. Kategorisasi untuk aspek program disajikan pada tabel 2 berikut ini:

Tabel 2. Kategorisasi Data Procces

\begin{tabular}{ccccc}
\hline Interval Skor & $\mathbf{f}$ & $\mathbf{( \% )}$ & Kategori \\
\hline$x$ & $\geq 39,00$ & 35 & 35,0 & Sangat baik \\
$30,00 \leq \mathrm{s.d}<39,00$ & 64 & 64,0 & Baik \\
21,00 & $\leq \mathrm{s.d}<30,00$ & 1 & 1,0 & Cukup \\
$x$ & $<21,00$ & 0 & 0,0 & Kurang \\
Total & 100 & 100,0 & \\
\hline
\end{tabular}

Hasil tabel diketahui sebesar 64\% responden menyatakan aspek program dalam kategori sangat baik, sebesar 35\% responden menyatakan aspek program dalam kategori baik. Responden yang 
Jurnal Keolahragaan, 9 (2), 2021-273

Fendi Nugroho, Wara Kushartanti, Guntur

menyatakan aspek program kategori cukup sebesar $1 \%$. Secara lebih jelas hasil kategorisasi data program dapat dilihat pada gambar 2 diagram berikut:

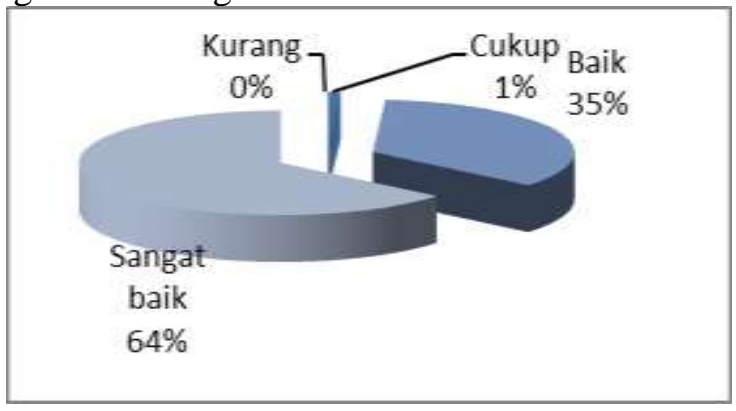

Gambar 2. Aspek Procces

\section{Aspek Product}

Evaluasi pada aspek produk mencakup hasil layanan dari manajemen dan penanganan cedera muskuloskeletal Klinik Terapi Fisik FIK UNY. Hasil analisis deskriptif aspek produk dari penilaian pasien Klinik Terapi Fisik FIK UNY. Hasil analisis data produk diperoleh skor terendah adalah 7,00 dan skor tertinggi adalah 16,00. Hasil analisis statistik deskriptif diperoleh rerata $(\mathrm{M})=13,61$; Median $(\mathrm{Me})=14,00 ;$ Modus $(\mathrm{Mo})=12,00$ dan Simpangan Baku $(\mathrm{SB})=1,99$.

Selanjutnya data dikategorikan untuk mengetahui kecenderungan aspek produk menjadi empat kategori yaitu sangat baik, baik, cukup dan kurang. Kategorisasi data penelitian didasarkan pada nilai mean dan standar deviasi ideal atau teoritik. Aspek produk terdiri dari 4 item yang masing-masing mempunyai skor 1,2,3, dan 4. Nilai skor minimal skala produk adalah sebesar $4(1 \times 4)$, skor maksimal sebesar $16(4 \times 4)$, sehingga diperoleh rentang skor sebesar $12(16-4)$. Perhitungan standar deviasi (SD), pada data yang berdistribusi normal memiliki 6 satuan standar, maka nilai SD sebesar 2,00 diperoleh dari (12:6), dan nilai mean teoritis sebesar $10(16+4 / 2)$. Kategorisasi untuk aspek produk disajikan pada tabel 3. berikut ini

Tabel 3. Kategorisasi Data Procces

\begin{tabular}{|c|c|c|c|}
\hline Interval Skor & f & $(\%)$ & Kategori \\
\hline$x \geq 13,00$ & 62 & 62,0 & Sangat baik \\
\hline $10,00 \leq$ s.d $<13,00$ & 36 & 36,0 & Baik \\
\hline $7,00 \leq \mathrm{s} . \mathrm{d}<10,00$ & 2 & 2,0 & Cukup \\
\hline$x<7,00$ & 0 & 0,0 & Kurang \\
\hline Total & 100 & 100,0 & \\
\hline
\end{tabular}

Berdasarkan tabel di atas diketahui sebesar $62 \%$ responden menyatakan aspek produk dalam kategori sangat baik, sebesar 36\% responden menyatakan aspek produk dalam kategori baik. Responden yang menyatakan aspek produk kategori cukup sebesar $1 \%$. Secara lebih jelas hasil kategorisasi data produk dapat dilihat pada gambar 3 diagram berikut:

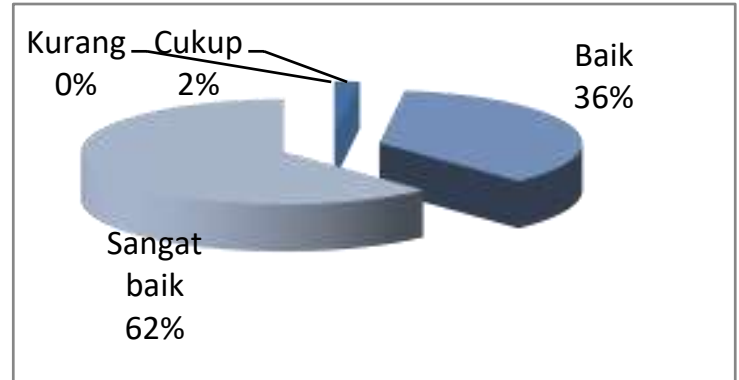

Gambar 3. Aspek Product 
Jurnal Keolahragaan, 9 (2), 2021-274

Fendi Nugroho, Wara Kushartanti, Guntur

\section{Pembahasan}

\section{Evaluasi pada Aspek Context}

Berdasarkan hasil penelitian berupa hasil wawancara pada narasumber menunjukkan bahwa aspek context sudah sangat baik. Hal tersebut ditunjukkan dari analisis kebutuhan masyarakat dan tujuan berdiri telah sesuai dengan kebutuhan masyarakat. Hasil dari wawancara oleh pelopor yang memiliki latar belakang berorganisasi dan merupakan dosen di Fakultas Ilmu Keolahragaan Universitas Negeri Yogyakarta, menjelaskan bahwasanya pembentukan ini berdasaran bentuk dari implementasi Tri Dharma Perguruan Tinggi, yaitu pengajaran dan pembelajaran dimana melalui laboratorium, yang memiliki, visi dan misi, tujuan, strategi, dan susnan organisasi yang jelas. Hasil penelitian dari Dahlan, (2019) menjelaskan bahwa budaya organisasi berhubungan positif terhadap kinerja,melalui implementasi inovasi, serta budaya organisasi dan inovasi berhubungan positif terhadap kinerja perusahaan.

Berdasarkan hasil wawancara yang dilakukan pada narasumber terutama dari pasien yang merupakan anggota masyarakat pengguna jasa pelayanan didapatkan hasil bahwa keberadaan Klinik Terapi Fisik FIK UNY memang telah sesuai dengan kebutuhan masyarakat. Dewasa ini banyak masyarakat yang memilih dan memanfaatkan terapi fisik untuk menangani cedera. Masyarakat tidak lagi berfokus pada pengobatan medis farmakologis (penggunaan obat), tetapi banyak yang memilih menggunakan terapi fisik untuk menangani cedera. Hasil data ini membuktikan bahwa pengaruh teknik efflurage dan teknik petrissage terhadap penurunan perasaan lelah pasca latihan (Jusuf et al., 2020).

Berdasarkan pernyataan tersebut, dapat diketahui bahwa terdapat kebutuhan masyarakat akan tempat terapi fisik untuk penganan cedera baik cedera akibat olahraga maupun akibat aktivitas seharihari. Keberadaan Klinik Terapi Fisik FIK UNY sangat membantu masyarakat dalam mengatasi masalah kesehatan terutama dalam penanganan cedera musculoskeletal. Klinik telah menjadi solusi bagi masyarakat yang ingin mendapatkan penganan cedera menggunakan terapi non farmakologis yaitu menggunakan terapi fisik berupa masase.

Context pendirian Klinik Terapi Fisik FIK UNY dilihat dari tujuan juga sudah tepat. Berdasarkan hasil wawancara dengan pihak terkait yaitu pelopor dan terapis awal diketahui bahwa tujuan pendirian Keberadaan Klinik Terapi Fisik FIK UNY awalnya adalah sebagai laboratorium yang menunjang proses pengajaran dalam perkuliahan mahasiswa terutama jurusan terapi. Pada tahap selanjutnya klinik berkembang sebagai sarana pengabdian masyarakat yaitu melayani dan membantu masyarakat yang mengalami masalah cedera musculoskeletal.

Hasil pemaparan data di atas menunjukkan bahwa aspek context dari manajemen dan penanganan cedera muskuloskeletal Klinik Terapi Fisik FIK UNY sudah terpenuhi sangat baik.

\section{Evaluasi pada Aspek Input}

Hasil perhitungan aspek input manajemen dan penanganan cedera muskuloskeletal Klinik Terapi Fisik FIK UNY dalam kategori sangat baik (51\%). Hasil analisis pada nilai rerata total skor aspek input adalah sebesar $81,59 \%$, yang menunjukkan bahwa dilihat dari hasil analisis tiap-tiap butir pertanyaan secara keseluruhan aspek input juga telah dilakukan dengan sangat baik.

Dilihat dari hasil analisis tiap-tiap butir pertanyaan judiketahuu persentase skor tertinggi ada pada pernyataan kecepatan front office menanggapi saat mendaftar dan menunggu dengan persentase sebesar $86 \%$. Hasil ini menunjukkan bahwa alur pelayanan yang dimulai dari front office telah dilakukan dengan sangat baik. Petugas front office telah memberikan pelayanan dengan cepat, ramah, beretika dan profesional.

Persentase skor terendah pada pernyataan lama waktu menunggu dengan nilai persentase sebesar $68,75 \%$. Hal ini dapat disebabkan karena penanganan terapi cedera membutuhkan waktu. Setiap pasien mempunyai tingkat keparahan cedera yang berbeda-beda sehingga waktu penanganan yang dilakukan juga berbeda. Hal ini menyebabkan pasien lain harus menunggu lama sampai penanganan cedera pada pasien sebelumnya selesai. Solusi yang diberikan dalam permasalahan ini adalah setiap pasien diberikan estimasi waktu penanganannya sehingga dapat menentukan sendiri apakah mau menunggu atau kembali lagi pada waktu yang telah ditentukan.

Input manajemen berupa sarana dan prasarana berdasarkan hasil observasi diketahui bahwa Klinik Terapi Fisik FIK UNY mempunyai sarana dan prasarana yang lengkap sebagai pendukung pelayanan terhadap pasien. Sarana Klinik Terapi Fisik FIK UNY diantaranya berupa sebuah bagunan 
gedung sebagai tempat praktik, terdapat halaman sekitar $30 \mathrm{~m}^{2}$ yang difungsikan sebagai tempat parkir. Selanjutnya terdapat ruang tunggu yang di dalamnya terdapat 4 kursi panjang terbuat dari besi dibagian halaman luar, terdapat 2 sofa panjang dan 3 kursi kecil. Tempat praktik juga ada front office sebagai tempat menerima pasien dengan 2 petugas front office yang bertugas mencatat dan mendata pasien yang mendaftar dan melakukan pembayaran. Ruang terapi ada sebanyak 5 ruangan masase. Terdapat 2 ruangan masseur, yaitu 1 ruangan masseur dan 1 ruangan masseus.

Prasana pendukung pelaksanaan terapi di Klinik Terapi Fisik FIK UNY meliputi tempat tidur sebanyak 5 dipan yang terbuat dari kayu. Ada kasur sebanyak 5 buah, handuk 30 buah, lotion tersedia dalam satu bulan \pm 30 botol, guling dan bantal masing-masing ruangan ada 5, 1 rak untuk menyimpan baju, handuk, sprei, dan lotion. Dilengkapi juga dengan baju pasien sebanyak 30 biji, celana pasien 50 biji, AC 4 ac yang ada di dalam klinik.

Pelengkap lain yaitu 1 buah vas bunga di meja front office, dan 5 gambar lukisan di dalam ruangan, dua rak sepatu berukuran panjang yang berada di halaman depan, 1 buah keset di pintu masuk dan terdapat 1 buah keset di bagian kamar mandi, dan pot bunga di halaman beserta tanamannya.Terdapat papan informasi ada di bagian depan halaman, 1 buah set PC dan printer di bagian front office, tempat sampah di setiap rungan, di halaman, kamar mandi dan di ruang tunggu, dan terdapat 2 buah jam dinding. Keseluruhan fasilitas, sarana dan prasarana yang ada di Terapi Klinik Terapi Fisik FIK UNY yang menunjang untuk memberikan terapi secara optimal. Diperkuat oleh hasil penelitian Sofyan et al. (2013) menyebutkab bahwa bahwa fasilitas, kualitas pelayanan dan kepuasan berpengaruh positif dan signifikan terhadap loyalitas.

Terapis di Klinik Terapi Fisik FIK UNY saat ini berasal dari mahasiswa IKORA jurusan terapi. Seleksi perekrutan terapis dimulai sehak semester 5 pada saat mahasiswa melakukan PKL. Selanjutnya mahasiswa dapat melamar kerja di Klinik dan harus magang 3 bulan baru ditentukan apakah diterima atau tidak. Mahasiswa yang berkompeten dan mempunyai keahlianlah yang akan dipilih dan diterima untuk bekerja di Klinik Terapi Fisik FIK UNY.

\section{Evaluasi pada Aspek Procces}

Hasil analisis data perhitungan aspek program manajemen dan penanganan cedera muskuloskeletal Klinik Terapi Fisik FIK UNY dalam kategori sangat baik (64\%). Hasil analisis pada nilai rerata total aspek process sebesar $84,90 \%$, yang menunjukkan bahwa aspek program mencakup cara layanan, cara penanganan, dan sistem pelaporan dari manajemen dan penanganan cedera muskuloskeletal Klinik Terapi Fisik FIK UNY telah dilakukan dengan sangat baik.

Klinik Terapi Fisik FIK UNY memberikan pelayanan kepada pasien berupa masase relaksasi dan masase terapi cedera ringan. Dalam memberikan pelayanan kepada masyarakat manajemen menerapkan program untuk melaksanakan rencana strategi dalam rangka mencapai tujuan. Program yang diterapkan meliputi cara pelayanan, cara penanganan dan sistem pelaporan. Cara pelayanan merupakan langkah-langkah yang dilakukan oleh seluruh komponen yang ada di Klinik Terapi Fisik FIK UNY dalam melayani pasien. Cara pelayanan tersebut dilakukan di seluruh bagian mulai dari front office, ruang tunggu, ruang masase dan di lingkungan. Klinik Terapi Fisik FIK UNY menerapkan prosedur pelayanan yang harus dilakukan oleh seluruh petugas dan terapis dalam melayani pasien.

Aspek program pada sistem pelayanan berdasarkan hasil observasi diketahui cara pelayanan di front office didapatkan hasil petugas memberikan respon yang cepat dalam melayani pendaftaran, pencatatan, dan rekapitulasi data. Petugas ramah dalam melayani dengan selalu menyapa "gretting", senyum kepada setiap pasien. Petugas juga meunjukkan sikap empati dengan menanyakan keluhan yang dialami pasien. Sikap professional petugas dapat dilihat dari cara berpakaian rapi, menerima kritik dan saran dari pasien, menjelaskan prosedur pelayanan kepada pasien, mencatat data pasien dengan rapi, memberikan kuitansi pembayaran kepada pasien, menyampaikan kondisi pasien apakah bisa dilakukan penanganan atau tidak. Etika petugas dalam melayani ditunjukkan dari cara mempersilahkan pasien untuk duduk sebelum melakukan pendaftaran, menanyakan keluhan yang dialami, mempersilahkan pasien untuk menjelaskan keluhan yang dialami, berbicara secara pelan tidak emosi.

Hasil observasi terhadap cara pelayanan di ruang tunggu didapatkan hasil petugas ramah dalam melayani pasien. Etika petugas ditunjukkan dengan memberikan pasien waktu untuk menjelaskan keluhan tanpa memotong. Petugas menjaga kebersihan yaitu setiap sebelum dilakukan proses pelayanan, dicek dan dilakukan kerapihan serta kebersihan. Ruang tunggu dibuat senyaman mungkin 
Jurnal Keolahragaan, 9 (2), 2021-276

Fendi Nugroho, Wara Kushartanti, Guntur

agar pasien tidak merasa bosan menunggu antrian dengan penataan tempat duduk ditata secara baik, namun kondisi sarana dan prasarana yang sudah mulai rusak menjadikan berkurangnya tingkat kenyamanan saat di ruang tunggu. Petugas juga memberikan estimasi waktu diberikan dari pihak front office untuk memastikan pasien menunggu atau ditinggal terlebih dahulu. Kendala yang dihadapi di ruang tunggu yaitu ruang tunggu kurang luas, sehingga saat banyak pasien yang mengantri terasa penuh sesak membuat tidak nyaman, hal seperti ini perlu dibahas lebih lanjut dalam bentuk evaluasi dari pihak manajemen. Senada hasil penelitian dari Tunggul et al. (2016) manajemen bisnis strategis mempunyai peranan penting untuk evaluasi kinerja sesuai dengan visi misi organisasi.

Hasil observasi terhadap cara pelayanan di ruang masase diketahui kebersihan ruang menunjukkan kondisi yang baik dimana ruangan selalu dalam kondisi keadaan yang bersih, baik pada saat sebelum dan sesudah digunakan dalam melakukan penanganan masase terapi. Kerapian ruangan juga terjaga karena terapis merapikan sebelum dan sesudah dilakukan penanganan masase terapi. Etika terapis dalam melayani pasien juga sopan yaitu mempersilahkan pasien dan menghantar untuk memasuki ruang masase dan mempersilahkan untuk mengganti pakaian atau celana yang sudah disiapkan, terapis mengetuk pintu sebelum memasuki ruangan masase, cara pelayanan tersebut merupakan indikator penilaian kerja. Senada dengan hasil penelitian Hartono \& Setiawardani (2017) bahwa terdapat hubungan yang kuat antara penilaian kinerja dengan komitmen organisasi karyawan. pengaruh dari penilaian kinerja berpengaruh positif sebesar 46,6\% terhadap komitmen organisasi karyawan sedangkan sisanya 53,4\% dipengaruhi oleh faktor lain seperti kepuasan kerja, karakteristik pekerjaan.

Terapis juga melayani dengan ramah yaitu mengucapkan salam, senyum, dan sapa kepada pasien. Empati ditunjukkan terapis dengan menanyakan keluhan yang dialami pasien. Profesionalisme terapis terlihat dari perilaku saat melayani pasien selalu memakai seragam, meyiapkan sarana untuk masase, dan melakukan masase sesuai dengan standar yang telah ditetapakan, melakukan anamnesis, melakukan masase record, memberikan saran kepada pasien untuk proses pemulihan pasien.

Hasil observasi pada kondisi lingkungan klinik diketahui kebersihan lingkungan klinik selalu terjaga karena petugas membersihkan secara berkala sebelum buka, saat dan setelah tutup sesuai dengan jadwal piket yang telah ditentukan. Kerapian likungan terlihat dari penataan parkir sudah diatur oleh petugas parkir, sudah diberikan tempat untuk menyimpan alas kaki, disediakan keset, penataan baju, celana, lotion dan handuk juga sudah ditata. Segi keamaan tidak ada satpam di area pelayanan, tetapi lingkungan tetap aman karena berada dalam pagar tinggi dan petugas front office di bagian depan dapat melihat siapa saja yang keluar masuk area klinik. Kedisiplinan terapis terlihat dari jam kerja yang sudah diteteapkan, yaitu pada saat terapis masuk dan pulang sesuai dengan jam kerja yang telah ditetapkan. Senada dengan hasil penelitian Ningsih et al., (2018) menunjukkan bahwa dimensi kualitas layanan seperti reliability, responsiveness, assurance, emphaty, tangible memiliki hubungan positif dengan kepuasan konsumen artinya semakin baik dimensi kualitas layanan diterapkan maka semakin meningkatkan kepuasan konsumen.

Berdasarkan hasil wawancara pada narasumber di atas diketahui bahwa proses pelaporan pendapatan dilakukan dengan merekap data pasien setiap hari dan dilaporkan ke pihak fakultas selama satu bulan penuh. Pencatatan yang dilakukan di klinik yaitu dicatat setiap hari jumlah pasien yang datang, selanjutnya dilaporkan setiap bulan. Data berupa kartu pasien, rekap data pasien (identitas, tempat tanggal lahit, alamat). Sistem monitoring dilakukan oleh pihak pengelola (kampus FIK UNY) melalui pelaporan penghasilan pasien setiap bulan, mulai dari pendapatan dan pengeluaran. Evaluasi dilakukan oleh pihak pengelola dan kepala Klinik Terapi Fisik FIK UNY setiap satu bulan sekali.

\section{Evaluasi pada Aspek Product}

Hasil perhitungan pada aspek product didapatkan hasil analisis aspek produk manajemen dan penanganan cedera muskuloskeletal Klinik Terapi Fisik FIK UNY dalam kategori sangat baik. Hasil analisis pada nilai rata-rata skor total butir pertanyaan adalah sebesar $85,06 \%$. Hasil ini menunjukkan bahwa aspek produk yaitu hasil layanan dari manajemen dan penanganan cedera muskuloskeletal Klinik Terapi Fisik FIK adalah sangat baik. Hasil penelitian lain yang dilakukan oleh (Falaahudin \& Sugiyanto, 2013) di klub renang menunjukan evaluasi produk yang baik dibuktikan dengan pencapaian prestasi dalam penelitian ini hasil baik merujuk dan dibuktikan dengan kepuasan pasien terhadap hasil penanganan.Pernyataan tersebut diperkuat oleh hasil penelitian Utomo \& Kushartanti (2019) diketahui masase frirage lebih baik untuk menyembuhkan nyeri pinggang akut sedangkan 
Jurnal Keolahragaan, 9 (2), 2021-277

Fendi Nugroho, Wara Kushartanti, Guntur

kombinasi back massage-stretching lebih baik untuk menyembuhkan nyeri pinggang kronis di Klinik Terapi Fisik FIK UNY.

Produk dari penanganan cedera muskuloskeletal Klinik Terapi Fisik FIK UNY dilihat dari hasil layanan yang diberikan. Hasil layanan tersebut dinilai oleh pasien yang telah memanfaatkan dan merasakan langsung penanganan cedera muskuloskeletal Klinik Terapi Fisik FIK UNY. Pengalaman yang dialami dan dirasakan langsung oleh pasien membuat pasien mampu menilai hasil layanan yang telah diberikan. Hasil penelitian Pawestriningtyas \& Suyadi (2016) menunjukkan bahwa empati memiliki pengaruh yang paling besar dalam pembentukan kepuasan.

Berdasarkan wawancara tersebut diketahui diketahui dari ketiga narasumber merasa puas dan senang dengan hasil layanan Klinik Terapi Fisik FIK UNY. Kepuasan terlihat dari penanganan yang diberikan mampu mempercepat kesembuhan yang ditunjukkan dengan bertambahnya fungsi sendi setelah penanganan terapi masase, penurunan rasa nyeri setelah terapi masase serta kenyamanan setelah penanganan terapi masase. Selain itu pasien juga puas dengan harga murah serta terapi fisik di Klinik Terapi Fisik FIK UNY dapat mengurangi risiko pemakaian obat. Penelitian yang sudah dilakukan sebelumnya tentang evaluasi dengan model CIPP oleh Irmansyah (2017) untuk menentukan hasil evaluasi dapat dilakukan dengan membandingkan hasil evaluasi dua kelompok dimana penelitian ini membandingkan pembinaan bola voli pantai di Provinsi NTB dan di DIY dan diperoleh beberapa rekomendasi. Hasil penelitian ini diperkuat oleh Fikri et al., (2016) kualitas pelayanan memiliki pengaruh yang signifikan terhadap kepuasan konsumen dan kepuasan yang dirasakan oleh konsumen berpengaruh signifikan terhadap kepercayaan atau loyalitas konsumen. Hasil penelitian pendukung lain menjelaskan lain menjelaskan bahwa kualitas yang dimiliki sebuah produk berpengaruh secara menyeluruh terhadap kepuasan konsumen sedangkan sebuah nominal harga tidak berpengaruh secara umum terhadap kepuasan konsumen (Setyo, 2017) hal ini menunjukan bahwa kepuasan konsumen lebih kepada kualitas produk yang diharapkan atau harapan, dalam penelitian ini mengarah kepada pemulihan cedera yang dialami pasien.

Kepuasan pasien merupakan salah satu indikator dari hasil pelayanan yang baik. Artinya manajemen dan penanganan cedera muskuloskeletal Klinik Terapi Fisik FIK UNY telah memberikan pelayanan yang baik sehingga dapat mewujudkan kepuasan pada pasien. Kepuasan pasien mengindikasikan kesesuaian antara harapan dan pelayanan. Artinya pasien telah merasa puas karena terapi fisik yang didapatkan dari Klinik Terapi Fisik FIK UNY telah sesuai dengan harapannya.

\section{SIMPULAN}

Evaluasi manajemen dan penanganan cedera muskuloskeletal klinik terapi Fisik FIK UNY dilihat dari aspek context telah sesuai dengan kebutuhan masyarakat, aspek input didapatkan hasil analisis dalam kategori sangat baik, aspek procces didapatkan hasil analisis dalam kategori baik, aspek product didapatkan hasil analisis dalam kategori sangat baik. Hal ini berimplikasi bahwa manajemen yang sekarang ini diterapkan dapat dilanjutkan. Rekomendasi untuk pihak FIK dan manajemen selaku pengelola adalah perlunya perbaikan pada tempat tunggu pasien yang diperluas dan sarana prasarana secara berkala dilakukan pengececkan kelayakan pemakaian mengingat semakin tingginya minat dan animo masyarakat yang melakukan terapi di Klinik Terapi Fisik FIK UNY.

\section{DAFTAR PUSTAKA}

Al-Khathami, A. D. (2012). Evaluation of Saudi family medicine training program: The application of CIPP evaluation format. Medical Teacher, 34(sup1), S81-S89.

Arifin, Z. (2009). Evaluasi pembelajaran. Bandung: PT Remaja Rosdakarya.

Barnes, P. M., Powell-Griner, E., McFann, K., \& Nahin, R. L. (2004). Complementary and alternative medicine use among adults: United States, 2002. Seminars in Integrative Medicine, 2(2), 54-71.

Chairawati, F. (2014). Evaluasi pembelajaran pada kelas internasional fakultas dakwah IAIN ArRaniry. Jurnal Al-Bayan: Media Kajian Dan Pengembangan Ilmu Dakwah, 20(1).

Chyung, S. Y. (2015). Foundational concepts for conducting program evaluations. Performance Improvement Quarterly, 27(4), 77-96.

Dahlan, M. (2019). Analisis hubungan antara budaya organisasi dan implementasi innovation types 
Jurnal Keolahragaan, 9 (2), 2021-278

Fendi Nugroho, Wara Kushartanti, Guntur

dan dampanya pada kinerja manajer. Sosiohumaniora, 21(1), 78-82.

Ernst, E. (2000). Prevalence of use of complementary/alternative medicine: a systematic review. Bulletin of the World Health Organization, 78, 258-266.

Falaahudin, A., \& Sugiyanto, F. X. (2013). Evaluasi program pembinaan renang di klub tirta serayu, tcs, bumi pala, dezender, spectrum di provinsi jawa tengah. Jurnal Keolahragaan, 1(1), 13-25.

Fikri, S., Wiyani, W., \& Suwandaru, A. (2016). Pengaruh kualitas pelayanan terhadap kepuasan \& loyalitas mahasiswa (studi pada mahasiswa strata i fakultas ilmu sosial dan ilmu politiku niversitas merdeka malang). Jurnal Bisnis Dan Manajemen, 3(1).

Hakan, K., \& Seval, F. (2011). CIPP evaluation model scale: development, reliability and validity. Procedia-Social and Behavioral Sciences, 15, 592-599.

Hartono, A. R., \& Setiawardani, M. (2017). Pengaruh evaluasi kinerja terhadap komitmen organisasional karyawan. Jurnal Riset Bisnis Dan Investasi, 3(1), 73-85.

Hasan, A., Yasin, S. N. T. M., \& Yunus, M. F. M. (2015). A conceptual framework for mechatronics curriculum using Stufflebeam CIPP Evaluation Model. Procedia-Social and Behavioral Sciences, 195, 844-849.

Irmansyah, J. (2017). Evaluasi program pembinaan prestasi cabang olahraga bola voli pantai. Jurnal Keolahragaan, 5(1), 24. https://doi.org/10.21831/jk.v5i1.12759

Jusuf, J. B. K., Raharja, A. T., Mahardhika, N. A., \& Festiawan, R. (2020). Pengaruh teknik effleurage dan petrissage terhadap penurunan perasaan lelah pasca latihan Pencak Silat. Jurnal Keolahragaan, 8(1), 1-8.

Kirana, K. C., \& Ratnasari, R. T. (2017). Evaluasi Kinerja Sumber Daya Manusia (SDM). Gosyen Publishing, Sleman Yogyakarta.

Mardapi, D. (2012). Pengukuran penilaian \& evaluasi pendidikan. Yogyakarta: Nuha Medika, 45.

Muryadi, A. D. (2017). Model evaluasi program dalam penelitian evaluasi. Jurnal Ilmiah Penjas (Penelitian, Pendidikan Dan Pengajaran), 3(1).

Musanto, T. (2004). Faktor-faktor kepuasan pelanggan \& loyalitas pelanggan: studi kasus pada CV. Sarana Media Advertising Surabaya. Jurnal Manajemen Dan Kewirausahaan (Journal of Management and Entrepreneurship), 6(2), 123-136.

Ningsih, D. A., Imron, A., \& Triwiyanto, T. (2018). Hubungan persepsi tentang kualitas dan pelayanan pendidikan dengan kepuasan orang tua siswa sekolah menengah kejuruan negeri. JAMP: Jurnal Administrasi Dan Manajemen Pendidikan, 1(2), 245-254.

Pawestriningtyas, N. C., \& Suyadi, I. (2016). Pengaruh kualitas pelayanan jasa terhadap kepuasan nasabah (survei pada nasabah perum pegadaian kantor cabang syariah tlogomas malang). Jurnal Administrasi Bisnis, 32(2), 39-46.

Setyo, P. E. (2017). Pengaruh Kualitas Produk dan Harga Terhadap Kepuasan Konsumen Best Autoworks. Jurnal Manajemen Dan Start-Up Bisnis, 1(6), 755-764.

Sofyan, I. L., Pradhanawati, A., \& Nugraha, H. S. (2013). Pengaruh fasilitas \& kualitas pelayanan terhadap loyalitas, melalui kepuasan konsumen sebagai variabel intervening pada star clean car wash Semarang. Jurnal Ilmu Administrasi Bisnis.

Stufflebeam, D. L., \& Zhang, G. (2017). The CIPP evaluation model: How to evaluate for improvement and accountability. Guilford Publications.

Tunggul, A. M., Isnanto, R., \& Nurhayati, O. D. (2016). Evaluasi kinerja organisasi publik dengan menggunakan pendekatan balanced scorecard dan analytic network process. Jurnal Sistem Informasi Bisnis, 6(2), 124-132.

Utomo, A., \& Kushartanti, B. M. W. (2019). Efektivitas massage frirage dan kombinasi back massagestretching untuk penyembuhan nyeri pinggang. Jurnal Keolahragaan, 7(1), 43-56. 